\title{
Wskaźnik średniej rocznej erozyjności deszczu i spływu powierzchniowego (R) na przykładzie stacji meteorologicznej w Lazach k. Bochni (region klimatu Pogórza Karpackiego)
}

\author{
Mean annual $R$ factor for Lazy near Bochnia meteorological station (Carpathian Foothills \\ climatic region)
}

\author{
Jolanta Święchowicz \\ Instytut Geografii i Gospodarki Przestrzennej, Uniwersytet Jagielloński, Kraków, j.swiechowicz@geo.uj.edu.pl
}

Zarys treści: Wskaźnik rocznej erozyjności deszczu i spływu powierzchniowego (R) jest jednym z parametrów empirycznego równania USLE (Uniwersalnego Równania Strat Glebowych) oraz innych modeli (np. RUSLE - Revised Universal Soil Loss Equation, USPED - Unit Stream Power based Erosion/Deposition). Jak dotąd nie dokonano szczegółowej charakterystyki erozyjności deszczów w Polsce, a wartości wskaźnika R zgodnie z procedurą opracowaną przez Wischmeiera i Smitha $(1965,1978)$ obliczono jedynie dla 13 stacji meteorologicznych. Celem pracy jest określenie wskaźnika erozyjności deszczu i spływu powierzchniowego (R) dla regionu klimatu Pogórza Karpackiego na podstawie pomiarów opadów atmosferycznych w wieloleciu 1987-2008 pochodzących ze stacji meteorologicznej w Łazach k. Bochni (Pogórze Wiśnickie). Średnia roczna z wielolecia 1987-2008 wartość wskaźnika R wynosi w Łazach 106,6 MJ cm ha ${ }^{-1} \mathrm{~h}^{-1}$. Jest ona większa od wartości podawanych dla Polski zachodniej (Wrocław-Swojec), północnej (Elbląg), północno-wschodniej (Suwałki), centralnej (Otwock, Sandomierz, Puczniew), zbliżona do wartości podawanych dla Karpat (Lesko, Limanowa, Szymbark). Roczne wartości wskaźnika R zmieniały się w Łazach w bardzo szerokim zakresie od 27,7 do 455,9 $\mathrm{MJ} \mathrm{cm} \mathrm{ha}^{-1} \mathrm{~h}^{-1}$. Maksymalne miesięczne wartości wskaźnika $\mathrm{R}_{\mathrm{r}}$ w roku zmieniały się od 6,1 w lipcu (1993) do 428,7 $\mathrm{MJ} \mathrm{cm} \mathrm{ha}^{-1} \mathrm{~h}^{-1} \mathrm{w}$ czerwcu (2006). Największa potencjalna erozja wodna gleby uzależniona od erozyjności deszczu możliwa była w czerwcu, lipcu, maju i sierpniu.

Słowa kluczowe: wskaźnik erozyjności deszczu [EI 30 , wskaźnik R, USLE, region klimatu Pogórza Karpackiego, Polska

\begin{abstract}
Rainfall and runoff erosivity factor (R) is a key input parameter to the USLE (Universal Soil Loss Equation) and many other models (RUSLE - Revised Universal Soil Loss Equation, USPED - Unit Stream Power based Erosion/Deposition). There is still no precise characteristic of rainfall erosivity in Poland. Local R factor values, according to Wischmeier and Smith procedure $(1965,1978)$ were calculated only for 13 meteorological stations. The main aim of the paper is to estimate rainfall and runoff erosivity factor $(\mathrm{R})$ for the Carpathian Foothills climatic region on the basis of 1987-2008 rainfall data for Łazy near Bochnia meteorological station (Wiśnicz Foothills). The average rainfall and runoff factor (R) for Łazy calculated for the years 1987-2008 equalled 106.6 $\mathrm{MJ} \mathrm{cm} \mathrm{ha}^{-1} \mathrm{~h}^{-1}$. This value was bigger in comparison with the values for other locations in western (Wrocław-Swojec), northern (Elbląg) northeastern (Suwałki) or central Poland (Otwock, Sandomierz, Puczniew) and similar to the values for the Carpathians (Lesko, Limanowa, Szymbark). The annual values of R factor for Łazy ranged between 27.7 in 1993 and $455.9 \mathrm{MJ} \mathrm{cm} \mathrm{ha}^{-1} \mathrm{~h}^{-1}$ in 2006 . Maximum monthly values of rainfall factor $\mathrm{R}_{\mathrm{r}}$ in a year varied from 6.1 in July (1993) to $428.7 \mathrm{MJ} \mathrm{cm} \mathrm{ha}^{-1} \mathrm{~h}^{-1}$ in June (2006). The most intensive potential soil erosion by water due to erosivity of rains is likely to happen in June, July, May and August.
\end{abstract}

Key words: rainfall erosivity index $\left[\mathrm{EI}_{30}\right]$, R factor, USLE, Carpathian Foothills climatic region, Poland

\section{Wstęp}

W Karpatach natężenie erozji wodnej gleby na obszarach użytkowanych rolniczo jest zróżnicowane w przestrzeni i podlega wyraźnym sezonowym zmianom, które związane są ze sposobem użytkowania ziemi oraz z występowaniem opadów (Święchowicz 2012a). Opad atmosferyczny, który jest podstawowym czynnikiem inicjującym 
erozję wodną gleby, nie jest procesem ciągłym, a jego sumy zmieniają się $\mathrm{w}$ dość szerokim zakresie zarówno w krótkim czasie (np. w ciągu minuty, godziny, doby, miesiąca, roku), jak i w okresach dłuższych, wieloletnich. W ciągu roku zmienia się także postać opadu (ciekła, stała). Standardowe wyniki pomiarów opadów atmosferycznych prowadzonych na większości posterunków opadowych i stacji meteorologicznych w Polsce (Dreger 1981, Pruchnicki 1987) nie są wystarczające do szczegółowych badań przebiegu i intensywności procesów erozyjnych na obszarach użytkowanych rolniczo oraz do modelowania erozji wodnej gleb (Józefaciuk, Józefaciuk 1995, Święchowicz 2002, 2012a, Licznar, Łomotowski 2005). Skuteczność erozyjna deszczu zależy przede wszystkim od energii kinetycznej spadających kropel. Natomiast w okresie wiosennym (obok temperatury powietrza) na dynamikę topnienia śniegu epizodycznie wpływa również energia kinetyczna spadających kropel deszczu, rozbijających i rozdrabniających skonsolidowaną warstwę śniegu. Te prawidłowości zostały stwierdzone już w latach 50. ubiegłego wieku przez Wischmeiera, Smitha (1958, 1959), którzy na podstawie pomiarów terenowych i laboratoryjnych stwierdzili, że najlepiej charakteryzującym erozyjność deszczu, czyli zdolność do wywołania spływu powierzchniowego i erozji gleby, jest parametr $\mathrm{EI}_{30}$ (czynnik $\mathrm{EI}_{30}$ ) definiowany jako iloczyn energii kinetycznej deszczu i jego maksymalnego natężenia w określonym $i$ -tym przedziale czasu. Najbardziej uniwersalny okazał się 30-minutowy przedział czasu, chociaż w wielu opracowaniach stosowano również przedziały krótsze, np. 15-minutowe, 10-minutowe czy 5-minutowe. Wskaźnik $\mathrm{EI}_{30}$ stał się podstawą obliczania parametru rocznej erozyjności deszczu i spływu powierzchniowego (R), jednego z 6 parametrów Uniwersalnego Równania Strat Glebowych (Universal Soil Loss Equation - USLE) opracowanego w USA przez Wischmeiera, Smitha $(1965,1978)$ na podstawie wieloletnich badań erozji gleby w warunkach naturalnych oraz laboratoryjnych badań eksperymentalnych z użyciem symulatorów deszczu. Równanie to ma postać iloczynu logicznego:

$$
\mathrm{A}=\mathrm{R} \cdot \mathrm{K} \cdot \mathrm{L} \cdot \mathrm{S} \cdot \mathrm{C} \cdot \mathrm{P}
$$

gdzie:

A - średnia z wielolecia roczna masa gleby wyerodowanej z jednostki powierzchni zlewni $\left[\mathrm{t}^{\mathrm{h}} \mathrm{a}^{-1} \mathrm{rok}^{-1}\right]$,

$\mathrm{R}$ - średnia roczna erozyjność deszczów i spływów [Je $\left.\mathrm{rok}^{-1}\right]$,

$\mathrm{K}$ - podatność gleb na erozję $\left[\mathrm{tha}^{-1} \mathrm{Je}^{-1}\right]$,

L - współczynnik długości zbocza [-],

$\mathrm{S}$ - współczynnik spadku zbocza [-],

$\mathrm{C}$ - współczynnik rodzaju upraw i sposobu użytkowania $[-]$,

P - współczynnik zabiegów przeciwdziałających erozji $[-]$,

$\mathrm{Je}-$ jednostka erozyjna $=1 \mathrm{MJ} \mathrm{cm} \mathrm{ha}^{-1} \mathrm{~h}^{-1}$.

Powyższy wzór uwzględnia jednostki miar wskaźników w systemie metrycznym. W oryginalnej wersji
USLE (Wischmeier, Smitha 1965, 1978) używano jednostek w układzie US (amerykański), a sposób ich konwersji z układu US na system metryczny podany był w załączniku (Renard i in. 1997).

Erozyjność jest sparametryzowaną cechą opadu, która określa jego zdolność do wywołania procesów erozyjnych. Określa się ją za pomocą funkcji uwzględniającej sumę opadu (warstwę opadu), czas trwania i natężenie. Wskaźnik erozyjności jest podstawowym parametrem wykorzystywanym w wielu modelach prognozujących erozję gleby (np. USLE, RUSLE, USPED). Parametr R jest parametrem regionalnym, zależnym od okresów występowania deszczów wywołujących erozję (deszczów erozyjnych). Jego wyznaczenie wymaga wieloletnich serii pomiarów opadów atmosferycznych. Procedura wyznaczania wskaźnika na podstawie zapisów pluwiograficznych jest bardzo czasochłonna i pracochłonna. Stosowane w ostatnich latach urządzenia elektroniczne do pomiaru opadów ułatwiają opracowanie wyników i umożliwiają analizę wykraczającą poza półrocza letnie, ale nie są one wykorzystywane powszechnie i zwykle długość serii pomiarowej jest zbyt krótka, by można było w sposób miarodajny policzyć wskaźnik R. Zalecana minimalna długość serii pomiarowej opadów atmosferycznych wystarczająca do obliczenia średniego rocznego wskaźnika erozyjności deszczu i spływu powierzchniowego (R) wynosi 22 lata (Wischmeier, Smith 1978). W wielu krajach świata kompleksowa analiza tego parametru na licznych stacjach opadowych pozwoliła na wyznaczenie średnich rocznych rozkładów wskaźnika $\mathrm{R}$ i opracowanie map erozyjności deszczów (Wischmeier, Smith 1965, 1978, Obi, Salako 1985, Pauwelyn 1988, Malíšek 1990, Oduro-Afryie 1996, Qi i in. 2000, Loureiro, Coutinho 2001, Súri i in. 2002, Diodato 2004, Silva da 2004, Janeček i in. 2006, 2012, 2013, Capolongo i in. 2008, Salako 2008, Meusburger 2012).

Nie udało się do tej pory opracować mapy erozyjności deszczów w Polsce (Licznar, Rojek 2002, Baryła 2004, Licznar 2005). Powstały jedynie opracowania cząstkowe bazujące na danych opadowych pochodzących z różnych okresów i odnoszących się najczęściej tylko do jednego lub co najwyżej kilku posterunków meteorologicznych. W wielu opracowaniach stosowano uproszczone wskaźniki erozyjności, do których zalicza się wskaźnik erozyjności opadów Fourniera (Fournier 1960) oraz wskaźnik Arnoldusa (wskaźnik Fourniera w modyfikacji Arnoldusa) (Arnoldus 1978). Taka metodę zastosowała Lorenz (za Józefaciuk, Józefaciuk 1995), wyznaczając wskaźnik erozyjności metodą Fourniera na podstawie miesięcznych sum opadów.

Pierwsze w Polsce opracowania poświęcone metodzie obliczania erozyjności deszczów według modelu USLE oraz zróżnicowaniu i zmienności tego wskaźnika dla obszarów centralnej i wschodniej Polski opublikowane zostały w latach 90. ubiegłego wieku (Banasik, Górski 1990, 1993, Banasik i in. 1995). W późniejszym okresie powstały kolejne prace, w których podawano wartości współczynnika R, który najczęściej obliczany był na 
podstawie wieloletnich danych pochodzących z pojedynczych stacji meteorologicznych usytuowanych w różnych regionach Polski (Licznar, Rojek 2002, Baryła 2004) oraz na obszarach, gdzie prowadzone były stacjonarne badania procesów erozji gleby (Rejman 2005, Demczuk 2008, 2009, Smolska 2010, Stępniewski i in. 2010, Święchowicz 2010, 2012a,b).

Celem pracy jest określenie wskaźnika erozyjności deszczu i spływu powierzchniowego (R) w wieloleciu na podstawie pomiarów opadów atmosferycznych pochodzących ze stacji meteorologicznej IGiGP UJ w Łazach k. Bochni.

\section{Obszar i metoda badań}

Badania przeprowadzono w oparciu o dane opadowe pochodzące ze stacji meteorologicznej Instytutu Geografii i Gospodarki Przestrzennej Uniwersytetu Jagiellońskiego w Łazach k. Bochni, położonej w regionie klimatycznym Pogórza Karpackiego (Niedźwiedź, Obrębska-Starklowa 1991, Cebulska i in. 2013). Posterunek meteorologiczny zlokalizowany jest na wierzchowinie w zlewni Dworskiego Potoku na wysokości 245 m n.p.m. Współrzędne geograficzne obiektu wynoszą odpowiednio $49^{\circ} 57^{\prime} 55^{\prime} \mathrm{N}$ i 20²9'43'"E (ryc. 1).

W opracowaniu wykorzystano zapisy pluwiograficzne $\mathrm{z}$ wielolecia 1987-2008. Dane nie były kompletne i nie do końca jednorodne. Brakowało pasków pluwiograficznych z roku 1992 oraz z czerwca i lipca roku 1996. Wskaźniki dla tych lat zostały policzone na podstawie zestawień pluwiograficznych oraz szczegółowych zapisów z dzienniczków meteorologicznych. Dane opadowe z lat 1987-1989 pochodziły z zapisów pluwiograficznych dokonywanych

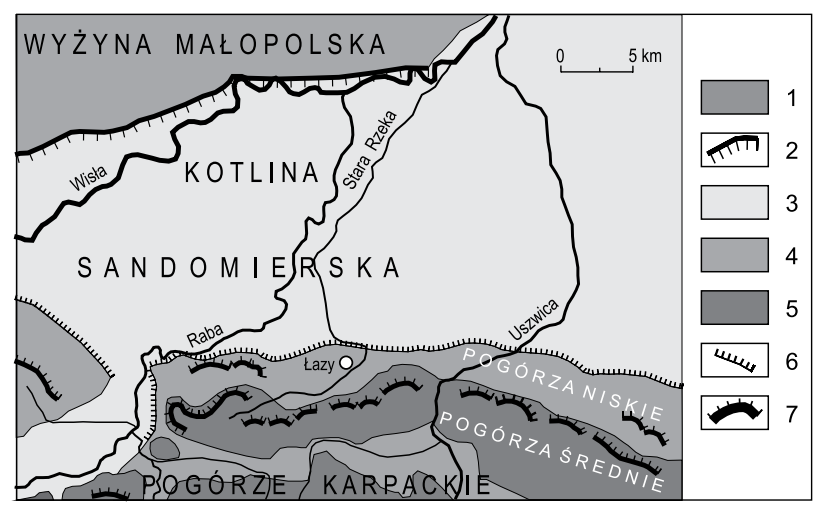

Ryc. 1. Położenie stanowiska badań (na podstawie Starkel 1988, Gilewska, Starkel 1979, 1988)

1 - Wyżyna Małopolska, 2 - krawędź Wyżyny Małopolskiej, 3 - Kotlina Sandomierska

Pogórze Karpackie: 4 - pogórza niskie, 5 - pogórza średnie, 6 krawędzie strukturalno-denudacyjne, 7 - krawędzie na czołach nasunięć

Fig. 1. Location of study site (based on Starkel 1988, Gilewska, Starkel 1979, 1988)

1 - Małopolska Upland, 2 - Małopolska Upland escarpments, 3 - Sandomierz Basin

Carpathian Foothills: 4 - low hills, 5 - medium hills, 6 - low hills escarpments, 7 - medium hills escarpments na paskach tygodniowych, natomiast w pozostałym okresie na paskach dobowych.

Wartość wskaźnika rocznej erozyjności deszczu i spływu powierzchniowego (R) jest sumą erozyjności deszczów i wywołanych nimi spływów $\left(\mathrm{R}_{\mathrm{r}}\right)$ oraz erozyjności spływów roztopowych $\left(\mathrm{R}_{\mathrm{s}}\right)$ (Wischmeier, Smith 1978):

$$
\mathrm{R}=\mathrm{R}_{\mathrm{r}}+\mathrm{R}_{\mathrm{s}}
$$

Wskaźniki $\mathrm{R}_{\mathrm{r}}$ i $\mathrm{R}_{\mathrm{s}}$ obliczono według tych samych procedur, które zostały podane $\mathrm{w}$ pracach Banasika i Górskiego (1990) oraz Banasika i in. (1995) i wykorzystane do obliczenia parametru $\mathrm{R}$ dla różnych stacji meteorologicznych w Polsce (Banasik, Górski 1990, 1993, Banasik i in. 1995, Licznar, Rojek 2002, Baryła 2004, Demczuk 2008, 2009). By wyniki były w pełni porównywalne, zastosowano również te same jednostki, czyli dla maksymalnego natężenia 30-minutowego deszczu były to $\mathrm{cm}^{-1}$, a dla erozyjności deszczu - $\mathrm{MJ} \mathrm{cm} \mathrm{ha}^{-1}$ $\mathrm{h}^{-1}$. Wskaźnik erozyjności deszczów i wywołanych nimi spływów powierzchniowych został obliczony w oparciu o zapisy pluwiograficzne deszczów erozyjnych. Do deszczów erozyjnych według kryterium USLE (Wischmeier, Smith 1978) zaliczane są deszcze oddzielone od siebie co najmniej 6-godzinną przerwą bez opadu lub z opadem mniejszym niż 0,05 cala (co w układzie SI odpowiada 1,3 $\mathrm{mm})$, o warstwie opadu $(\mathrm{P})$ większej lub równej 0,5 cala (co w układzie SI odpowiada 12,7 mm) lub mniejszej, jeśli spełniony jest następujący warunek: $\mathrm{I}_{\max } \geq 0,25$ cala 15 . $\min ^{-1}$, czyli $\mathrm{I}_{\max } \geq 6,3 \mathrm{~mm} \cdot 15 \cdot \mathrm{min}^{-1}$.

Dla każdego z tak wyróżnionych deszczów obliczono ich erozyjność $\left(\mathrm{R}_{\mathrm{rj}}\right)$ lub inaczej wskaźnik erozyjności $\left(\mathrm{EI}_{30}\right)$, czyli sparametryzowaną cechę deszczu w postaci iloczynu jego energii kinetycznej i maksymalnego natężenia 30-minutowego deszczu (Wischmeier, Smith 1978, Banasik, Górski 1990, 1993, Banasik i in. 1995):

$$
\mathrm{R}_{\mathrm{rj}}=\mathrm{E}_{\mathrm{k}} \mathrm{I}_{30} \cdot 0,01
$$

gdzie:

$\mathrm{R}_{\mathrm{rj}}$ - erozyjność j-ego deszczu [MJ $\left.\mathrm{cm} \mathrm{ha}^{-1} \mathrm{~h}^{-1}\right]$,

$\mathrm{I}_{30}{ }^{\mathrm{rj}}$ - maksymalne 30-minutowe natężenie deszczu [ $\left.\mathrm{cm} \mathrm{h}^{-1}\right]$, $\mathrm{E}_{\mathrm{k}}$ - energia kinetyczna deszczu $\left[\mathrm{J} \mathrm{m}^{-2}\right]$,

0,01 - współczynnik przeliczeniowy z $\mathrm{J} \mathrm{m}^{-2}$ na $\mathrm{MJ} \mathrm{ha}^{-1}$.

Wskaźnik średniej erozyjności deszczów i spływów $\left(\mathrm{R}_{\mathrm{r}}\right)$ jest sumą wskaźników erozyjności poszczególnych deszczów erozyjnych $\left(\mathrm{R}_{\mathrm{r} j}\right)$. W literaturze polskiej dla określenia erozyjności deszczu stosuje się również jednostkę erozyjności (Je) (Banasik i in. 1995):

$$
\mathrm{Je}=1 \mathrm{MJ} \mathrm{cm} \mathrm{ha}^{-1} \mathrm{~h}^{-1}
$$

O wartości wskaźnika $\mathrm{R}_{\mathrm{r}}$ decyduje energia kinetyczna kropel deszczu, której wyznaczenie wymaga znajomości średnicy i masy kropel deszczu, ilości kropel oraz prędkości ich spadania. Rozkład wielkości kropel deszczu zmienia się w szerokim zakresie w zależności od rodzaju 
opadów (Licznar, Łomotowski 2005, Szewrański 2009). Pomiar energii kinetycznej wymaga zastosowania zaawansowanych urządzeń pomiarowych (np. disdrometrów umożliwiających pomiar rozkładu wielkości kropel deszczu), które nie są jeszcze powszechnie używane na stacjach meteorologicznych w Polsce (Licznar i in. 2005, Szewrański 2009). Dlatego w celu obliczenia energii kinetycznej na podstawie dostępnych danych pochodzących $\mathrm{z}$ zapisów pluwiograficznych używa się równań, w których zmienną niezależną jest natężenie opadu.

Jednym $\mathrm{z}$ nich jest równanie opracowane na podstawie danych empirycznych zebranych głównie na stacjach meteorologicznych w środkowo-wschodniej części USA (Wischmeier, Smitha 1965, 1978). Natężenie opadu jest cechą o dużej regionalnej zmienności, dlatego w literaturze kwestionowano uniwersalność równania i proponowano inne (Dijk van i in. 2002, Salles i in. 2002). Wskaźnik $\mathrm{EI}_{30}(\mathrm{R})$ uwzględniający energię kinetyczną oraz maksymalne 30-minutowe natężenie jest nadal powszechnie używany do określania erozyjności deszczu, chociaż stosowane są różne formuły pozwalające na obliczenie energii kinetycznej na podstawie natężenia deszczu (Zanchi, Torri 1980, Brown, Foster 1987, Coutinho, Thomas 1994, Fornis i in. 2005, Nyssen i in. 2005).

W celu porównania wartości erozyjności deszczów w Łazach z wartościami erozyjności deszczów w innych regionach $\mathrm{w}$ Polsce do obliczenia energii kinetycznej deszczu zastosowano równanie Wischmeiera i Smitha (1965, 1978), które wykorzystywane było również do obliczenia wskaźnika R przez innych autorów w Polsce (Banasik, Górski 1990, 1993, Licznar, Rojek 2002, Baryła 2004, Demczuk 2008, 2009) oraz w krajach sąsiednich, np. na Słowacji (Malíšek 1990, Šúri i in. 2002), w Czechach (Janeczek i in. 2006, 2012). Równanie ma postać:

$$
E_{k i}=\left(206+87 \log I_{i}\right) \cdot P_{i} \text {, }
$$

gdzie:

$\mathrm{E}_{\mathrm{ki}}$ - energia kinetyczna $\mathrm{w}$ i-tym przedziale $\left[\mathrm{J} \mathrm{m}^{-2}\right]$,

$\mathrm{I}_{\mathrm{i}}$ - natężenie deszczu w i-tym przedziale $\left[\mathrm{cm} \mathrm{h}^{-1}\right]$,

$\mathrm{P}_{\mathrm{i}}$ - warstwa deszczu w i-tym przedziale [cm].

Obliczone wartości $\mathrm{EI}_{30}$ dla wszystkich deszczów mających zapisy pluwiograficzne pozwoliły na wyliczenie równania regresji erozyjności deszczu w funkcji warstwy deszczu (P). Równanie regresji umożliwiło policzenie wartości erozyjności deszczów, które nie miały zapisów pluwiograficznych, a ich sumy zostały zarejestrowane tylko deszczomierzem Hellmanna. Wyliczenie erozyjności wszystkich deszczów (zarówno mających zapisy pluwiograficzne, jak i nie mających) umożliwiło obliczenie rocznych wartości wskaźnika erozyjności deszczu $\left(\mathrm{R}_{\mathrm{r}}\right)$, wartości średniej z wielolecia oraz prześledzenie jego zmienności w poszczególnych miesiącach roku.

Erozyjność spływów roztopowych $\left(\mathrm{R}_{\mathrm{s}}\right)$ obliczono w sposób przybliżony, przyjmując, że jego wartość (wyrażona $\mathrm{w} \mathrm{MJ} \mathrm{cm} \mathrm{ha} \mathrm{C}^{-1} \mathrm{~h}^{-1}$ ) stanowi 0,1 sumy opadu (w $\mathrm{mm}$ ) w okresie od 1 grudnia do 31 marca (Banasik i in. 1995).

\section{Wyniki i dyskusja}

\section{Zmienność opadów atmosferycznych w latach 1987-2008}

Średnia roczna suma opadów w latach 1987-2008 wynosiła $662,4 \mathrm{~mm}$. Najbardziej suchy w wieloleciu był rok 2003. Roczna suma opadów wynosiła $442,4 \mathrm{~mm}$, co stanowiło zaledwie $66,8 \%$ średniej z wielolecia. Według klasyfikacji Kaczorowskiej (1962) rok ten był rokiem bardzo suchym. Najbardziej wilgotny był rok 2001 z roczną suma opadów wynoszącą $810,3 \mathrm{~mm}$, co stanowiło $122,3 \%$ średniego opadu z wielolecia. W badanym wieloleciu najczęściej występowały lata normalne $\mathrm{z}$ roczną sumą opadu zawierającą się pomiędzy 614,3 a 722,5 mm (blisko 50\% przypadków), w następnej kolejności lata wilgotne z roczną sumą opadu zawierającą się pomiędzy 739,6 a $810,3 \mathrm{~mm}$ (27,3\% przypadków). Pozostałe to lata suche z roczną sumą opadów pomiędzy 516,7 a $585,7 \mathrm{~mm}$ (13,6\% przypadków) i dwa lata (1988 i 2003) bardzo suche (tab. 1).

\section{Liczba deszczów erozyjnych}

W latach 1987-2008 wyróżniono 203 deszcze, które spełniały kryterium USLE i dla których istniały zapisy pluwiograficzne. Wśród nich 200 miało warstwę opadu (P) równą lub wyższą od $12,7 \mathrm{~mm}$, a tylko 3 niższą od $12,7 \mathrm{~mm}$, ale ich natężenie przekraczało $6,3 \mathrm{~mm} \cdot 15 \mathrm{~min}^{-1}$. Sumy opadów pojedynczych deszczów zmieniały się od 6,4 do $94 \mathrm{~mm}$. Liczba deszczów erozyjnych była zróżnicowana i wahała się od 3 (1993, 2003) do 16 (1989, 2001) przypadków. Średnio 9 w ciągu roku (ryc. 2). Liczba przypadków deszczów erozyjnych powyżej średniej częściej występowała w latach wilgotnych, natomiast najniższą ich liczbą charakteryzowały się lata bardzo suche i suche. Najwięcej przypadków deszczów erozyjnych miało miejsce w lipcu i czerwcu, najmniej w kwietniu i październiku (ryc. 3). Wartości indeksów erozyjności poszczególnych deszczów zmieniały się w bardzo szerokim zakresie i wynosiły od 0,3 do 376, $2 \mathrm{MJ} \mathrm{cm} \mathrm{ha}^{-1} \mathrm{~h}^{-1}$.

Dla 200 deszczów, których całkowita warstwa opadu przekraczała $12,7 \mathrm{~mm}$, obliczono zależność erozyjności deszczów $\left(\mathrm{EI}_{30}\right)$ od warstwy deszczu (P). Najlepsze dopasowanie dało zastosowanie funkcji potęgowej. Obliczony współczynnik korelacji (r) wyniósł 0,54 na poziomie istotności $\mathrm{p}=0,000$ (ryc. 4). Wartość współczynnika była niska, ale zbliżona do wartości w podobnych związkach dla stacji meteorologicznych Puławy, Sandomierz, Limanowa (Banasik i in. 1990), Wrocław-Swojec (Licznar, Rojek 2002), Puczniew (Baryła 2004). Funkcja pozwoliła na obliczenie erozyjności deszczów, dla których nie było zapisów pluwiograficznych, dzięki czemu możliwe było uzyskanie miesięcznych i rocznych wartości erozyjności spływów deszczowych $\left(\mathrm{R}_{\mathrm{r}}\right)$, erozyjności spływów roztopowych $\left(\mathrm{R}_{\mathrm{s}}\right)$ oraz wskaźnika $\mathrm{R}$ dla lat hydrologicznych 1987-2008 (tab. 1, 2). Tylko dla 29 deszczów w wielo- 
Tabela 1. Sumy wskaźników erozyjności deszczów $\left(\mathrm{EI}_{30}\right)$ obliczone w oparciu o zapisy pluwiograficzne i równanie regresji oraz roczne wartości wskaźnika erozyjności deszczów ( $\left.\mathrm{R}_{\mathrm{r}}\right)$ (Łazy k. Bochni, 1987-2008)

Table 1. Rainfall erosivity indexes $\left(\mathrm{EI}_{30}\right)$ calculated on the basis of hyetograph records and regression equation, and annual values of $\mathrm{R}_{\mathrm{r}}$ factor (Łazy near Bochnia, 1987-2008)

\begin{tabular}{|c|c|c|c|c|c|c|}
\hline Rok & $\begin{array}{c}\text { Roczna suma } \\
\text { opadów } \\
{[\mathrm{mm}]}\end{array}$ & Typ roku* & $\begin{array}{c}\text { Liczba } \\
\text { deszczów** }\end{array}$ & $\begin{array}{l}\mathrm{EI}_{30} \text { obliczone na podstawie } \\
\text { zapisów pluwiograficznych }\end{array}$ & $\begin{array}{l}\mathrm{EI}_{30} \text { obliczone } \\
\text { z równania*** }\end{array}$ & $\mathrm{R}_{\mathrm{r}}$ \\
\hline 1987 & 662,3 & $\mathrm{~N}$ & 11 & 28,8 & 2,3 & 31,1 \\
\hline 1988 & 492,8 & BS & 5 & 14,0 & 2,3 & 16,3 \\
\hline 1989 & 664,1 & $\mathrm{~N}$ & 16 & 101,4 & 0,0 & 101,4 \\
\hline 1990 & 552,3 & S & 9 & 37,4 & 4,4 & 41,8 \\
\hline 1991 & 629,1 & $\mathrm{~N}$ & 9 & 38,1 & 0,0 & 38,1 \\
\hline 1992 & 625,8 & $\mathrm{~N}$ & 9 & 47,9 & 3,0 & 50,9 \\
\hline 1993 & 516,7 & $\mathrm{~S}$ & 5 & 14,2 & 3,8 & 18,0 \\
\hline 1994 & 722,5 & $\mathrm{~N}$ & 8 & 30,5 & 11,4 & 41,9 \\
\hline 1995 & 618,6 & $\mathrm{~N}$ & 11 & 173,1 & 1,8 & 174,9 \\
\hline 1996 & 768,3 & W & 13 & 117,8 & 1,9 & 119,7 \\
\hline 1997 & 784,7 & W & 18 & 86,9 & 6,4 & 93,3 \\
\hline 1998 & 739,6 & W & 10 & 96,3 & 19,6 & 115,9 \\
\hline 1999 & 800,5 & $\mathrm{~W}$ & 15 & 133,0 & 1,8 & 134,8 \\
\hline 2000 & 664,8 & $\mathrm{~N}$ & 9 & 45,8 & 11,7 & 57,5 \\
\hline 2001 & 810,3 & $\mathrm{~W}$ & 20 & 135,9 & 7,2 & 143,1 \\
\hline 2002 & 710,3 & $\mathrm{~N}$ & 13 & 115,6 & 2,7 & 118,3 \\
\hline 2003 & 442,4 & BS & 4 & 9,1 & 1,7 & 10,8 \\
\hline 2004 & 614,3 & $\mathrm{~N}$ & 7 & 29,0 & 4,7 & 33,7 \\
\hline 2005 & 643,5 & $\mathrm{~N}$ & 11 & 154,8 & 0,0 & 154,8 \\
\hline 2006 & 720,6 & $\mathrm{~N}$ & 13 & 439,6 & 4,9 & 444,5 \\
\hline 2007 & 804,3 & W & 8 & 130,4 & 0,0 & 130,4 \\
\hline 2008 & 585,7 & $\mathrm{~S}$ & 7 & 29,1 & 0,0 & 29,1 \\
\hline Średnia & 662,4 & - & 10,5 & 91,3 & 4,2 & 95,5 \\
\hline$[\%]$ & - & - & - & 95,6 & 4,4 & 100,0 \\
\hline
\end{tabular}

* - według Kaczorowskiej (1962): BS - bardzo suchy, S - suchy, N - normalny, W - wilgotny

** - liczba deszczów erozyjnych (z zapisem pluwiograficznym i bez zapisu)

*** - wzór równania na ryc. 4

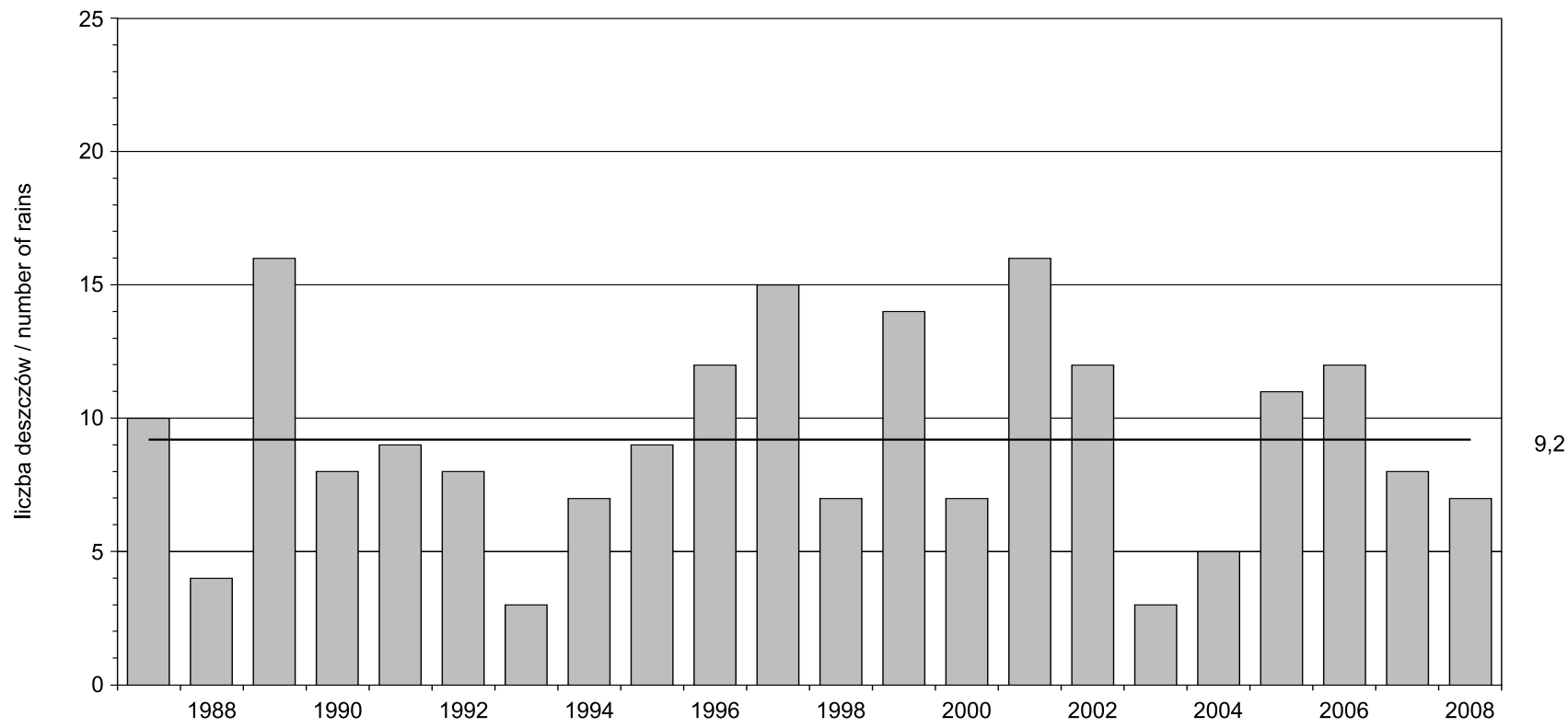

Ryc. 2. Roczna liczba przypadków deszczów erozyjnych wyróżnionych według kryterium USLE na podstawie zapisów pluwiograficznych (Lazy k. Bochni, 1987-2008)

Fig. 2. Annual number of erosive rains according to the USLE criterion based on hyetograph records (Lazy near Bochnia, 1987-2008) 


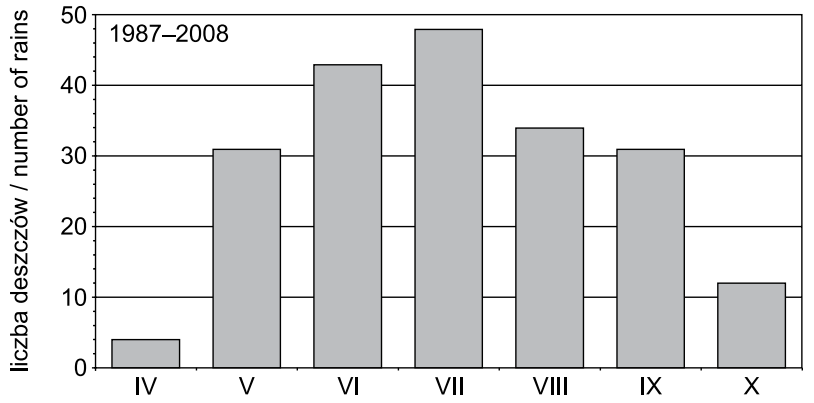

Ryc. 3. Miesięczna liczba przypadków deszczów erozyjnych wyróżnionych według kryterium USLE na podstawie zapisów pluwiograficznych (Łazy k. Bochni, 1987-2008)

Fig. 3. Monthly number of erosive rains according to the USLE criterion based on hyetograph records (Lazy near Bochnia, 1987-2008)

leciu, które spełniały kryterium USLE, indeks $\mathrm{EI}_{30}$ obliczono z funkcji, a jego wartość stanowiła zaledwie 4,4\% całkowitej wartości wskaźnika $\mathrm{R}_{\mathrm{r}}$ (tab. 1).

\section{Zmienność wskaźnika erozyjności deszczów i wywołanych nimi spływów $\left(R_{r}\right)$}

Roczne wartości wskaźnika $\mathrm{R}_{\mathrm{r}} \mathrm{w}$ wieloleciu zmieniały się w szerokim zakresie od 10,8 (2003) do 444,5 $\mathrm{MJ} \mathrm{cm} \mathrm{ha}^{-1}$ $h^{-1}$ (2006). Niskie roczne wartości wskaźnika $R_{r}$ zawsze występowały w latach suchych i bardzo suchych (1988, 1990, 1993, 2003, 2008), natomiast wysokie wartości notowano zarówno w latach wilgotnych, jak i w latach, w których roczne sumy opadów zbliżone były do średniej z wielolecia. Wartość najwyższa wskaźnika wystąpiła w roku 2006, a zadecydował o tym jeden deszcz o ekstremalnie wysokim natężeniu (tab. 2). Najwyższe średnie wartości wskaźnika $\mathrm{R}_{\mathrm{r}}$ wystąpiły w miesiącach let- nich (czerwiec, lipiec i sierpień) oraz wiosennych (maj). $\mathrm{W}$ tych miesiącach zanotowano od 11,2\% (sierpień) do $39,1 \%$ (czerwiec) całkowitej rocznej wartości wskaźnika $\mathrm{R}_{\mathrm{r}}$ (ryc. 5).

W poszczególnych latach w wymienionych miesiącach wartości wskaźnika zmieniały się w bardzo szerokim zakresie od 0 do 428,7 (czerwiec), 152,6 (maj), 88,6 (lipiec) i 48,6 (sierpień). Bardzo niskie średnie miesięczne wartości wskaźnika $\mathrm{R}_{\mathrm{r}}$ wystąpiły jesienią i wczesną wiosną i stanowiły one zaledwie od 0,3\% (listopad) do 3,5\% (kwiecień) średniej rocznej wartości wskaźnika (ryc. 5, tab. 2). Siła związku między miesięcznymi wartościami wskaźnika $\mathrm{R}_{\mathrm{r}}$ a miesięcznymi sumami opadów w tych miesiącach była różna. Najlepsze dopasowanie wystąpiło w kwietniu oraz w miesiącach letnich, a zwłaszcza w sierpniu i czerwcu (tab. 3), natomiast we wrześniu, październiku i listopadzie korelacja była niska. Częściowo wiąże się to z tym, że w miesiącach jesiennych występowało stosunkowo mało deszczów erozyjnych o warstwie przekraczającej $12,7 \mathrm{~mm}$.

$\mathrm{O}$ wysokich wartościach $\mathrm{R}_{\mathrm{r}}$ decyduje wystąpienie deszczów o wysokich sumach i dużych natężeniach. Roczne wartości wskaźnika $\mathrm{R}_{\mathrm{r}}$ są bardzo dobrze skorelowane z liczbą deszczów erozyjnych w ciągu roku. Najlepsze dopasowanie dało zastosowanie funkcji potęgowej o współczynniku korelacji $\mathrm{r}=0,80$ i poziomie istotności $p=0,018$ (ryc. 6A).

\section{Zmienność wskaźnika erozyjności spływów roztopowych $\left(R_{s}\right)$}

Wskaźnik erozyjności spływów roztopowych szacowany był w sposób przybliżony, jako 0,1 sumy opadów w miesiącach XII-III. Średnia wartość z wielolecia wyniosła

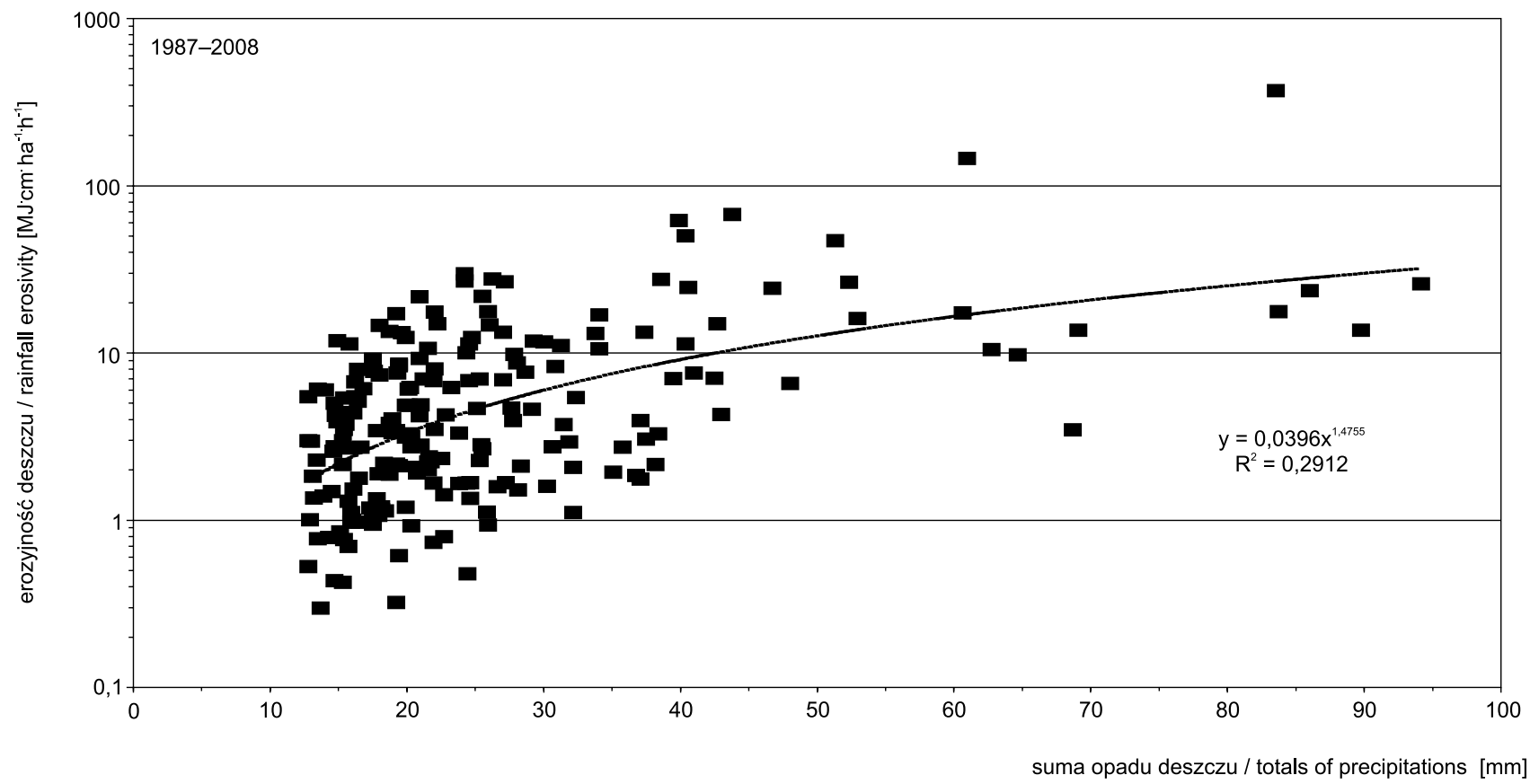

Ryc. 4. Erozyjność deszczów (EI ${ }_{30}$ ) w funkcji warstwy opadu (P) (Łazy k. Bochni, 1987-2008)

Fig. 4. Rainfall erosivity index $\left(\mathrm{EI}_{30}\right)$ as a function of rainfall depth (P) (Lazy near Bochnia, 1987-2008) 
Tabela 2. Miesięczne i roczne wartości wskaźnika erozyjności deszczów ( $\left.\mathrm{R}_{\mathrm{r}}\right)$ (Łazy k. Bochni, 1987-2008)

Table 2. Monthly and annual $R_{r}$ factor values (Lazy near Bochnia, 1987-2008)

\begin{tabular}{|c|c|c|c|c|c|c|c|c|c|c|c|c|c|}
\hline Rok & I & II & III & IV & $\mathrm{V}$ & VI & VII & VIII & IX & $X$ & XI & XII & Suma \\
\hline 1987 & 0,0 & 0,0 & 0,0 & 2,3 & 8,1 & 8,7 & 4,7 & 3,8 & 2,7 & 0,8 & 0,0 & 0,0 & 31,1 \\
\hline 1988 & 0,0 & 0,0 & 0,0 & 2,3 & 2,8 & 1,9 & 8,7 & 0,6 & 0,0 & 0,0 & 0,0 & 0,0 & 16,3 \\
\hline 1989 & 0,0 & 0,0 & 0,0 & 12,3 & 3,2 & 21,4 & 46,2 & 17,3 & 1,0 & 0,0 & 0,0 & 0,0 & 101,4 \\
\hline 1990 & 0,0 & 0,0 & 0,0 & 4,4 & 4,2 & 0,0 & 12,7 & 17,3 & 3,2 & 0,0 & 0,0 & 0,0 & 41,8 \\
\hline 1991 & 0,0 & 0,0 & 0,0 & 0,0 & 3,5 & 5,5 & 1,4 & 16,2 & 9,4 & 2,1 & 0,0 & 0,0 & 38,1 \\
\hline 1992 & 0,0 & 0,0 & 0,0 & 0,0 & 5,3 & 35,9 & 2,2 & 0,0 & 4,5 & 0,0 & 0,0 & 3,0 & 50,9 \\
\hline 1993 & 0,0 & 0,0 & 1,9 & 0,0 & 5,4 & 0,0 & 6,1 & 2,7 & 0,0 & 0,0 & 1,9 & 0,0 & 18,0 \\
\hline 1994 & 0,0 & 0,0 & 2,5 & 8,9 & 2,8 & 17,6 & 2,8 & 0,5 & 6,1 & 0,7 & 0,0 & 0,0 & 41,9 \\
\hline 1995 & 0,0 & 0,0 & 0,0 & 1,6 & 152,6 & 9,1 & 0,0 & 5,5 & 4,3 & 0,0 & 0,0 & 1,8 & 174,9 \\
\hline 1996 & 0,0 & 0,0 & 0,0 & 0,0 & 4,6 & 52,0 & 10,2 & 48,6 & 2,4 & 0,0 & 1,9 & 0,0 & 119,7 \\
\hline 1997 & 0,0 & 0,0 & 0,0 & 0,0 & 9,8 & 9,7 & 46,4 & 13,2 & 7,8 & 0,0 & 2,7 & 3,7 & 93,3 \\
\hline 1998 & 0,0 & 0,0 & 0,0 & 19,6 & 0,0 & 83,6 & 0,8 & 7,0 & 1,9 & 2,9 & 0,0 & 0,0 & 115,9 \\
\hline 1999 & 0,0 & 0,0 & 0,0 & 1,8 & 0,0 & 56,1 & 58,8 & 6,7 & 9,7 & 1,7 & 0,0 & 0,0 & 134,8 \\
\hline 2000 & 0,0 & 0,0 & 4,1 & 7,6 & 4,1 & 0,0 & 39,6 & 0,0 & 2,1 & 0,0 & 0,0 & 0,0 & 57,5 \\
\hline 2001 & 0,0 & 0,0 & 0,0 & 9,1 & 39,4 & 12,0 & 40,4 & 33,4 & 8,8 & 0,0 & 0,0 & 0,0 & 143,1 \\
\hline 2002 & 0,0 & 0,0 & 0,0 & 2,7 & 6,6 & 43,4 & 50,6 & 4,3 & 9,4 & 1,3 & 0,0 & 0,0 & 118,3 \\
\hline 2003 & 0,0 & 0,0 & 0,0 & 0,0 & 6,9 & 0,0 & 0,0 & 0,0 & 2,2 & 0,0 & 0,0 & 1,7 & 10,8 \\
\hline 2004 & 0,0 & 0,0 & 2,9 & 1,8 & 0,0 & 0,0 & 26,8 & 0,0 & 0,0 & 2,2 & 0,0 & 0,0 & 33,7 \\
\hline 2005 & 0,0 & 0,0 & 0,0 & 0,0 & 13,8 & 9,8 & 88,6 & 39,3 & 3,3 & 0,0 & 0,0 & 0,0 & 154,8 \\
\hline 2006 & 0,0 & 0,0 & 4,9 & 0,0 & 3,9 & 428,7 & 0,0 & 5,2 & 1,8 & 0,0 & 0,0 & 0,0 & 444,5 \\
\hline 2007 & 0,0 & 0,0 & 0,0 & 0,0 & 13,2 & 26,6 & 24,8 & 12,4 & 49,8 & 3,6 & 0,0 & 0,0 & 130,4 \\
\hline 2008 & 0,0 & 0,0 & 0,0 & 0,0 & 0,0 & 0,0 & 25,0 & 0,9 & 1,6 & 1,6 & 0,0 & 0,0 & 29,1 \\
\hline Średnia & 0,0 & 0,0 & 0,7 & 3,4 & 13,2 & 37,3 & 22,6 & 10,7 & 6,0 & 0,8 & 0,3 & 0,5 & 95,5 \\
\hline$[\%]$ & 0,0 & 0,0 & 0,8 & 3,5 & 13,8 & 39,1 & 23,7 & 11,2 & 6,3 & 0,8 & 0,3 & 0,5 & 100,0 \\
\hline$[\Sigma \%]$ & 0,0 & 0,0 & 0,8 & 4,3 & 18,1 & 57,3 & 80,9 & 92,1 & 98,4 & 99,2 & 99,5 & 100 & - \\
\hline
\end{tabular}

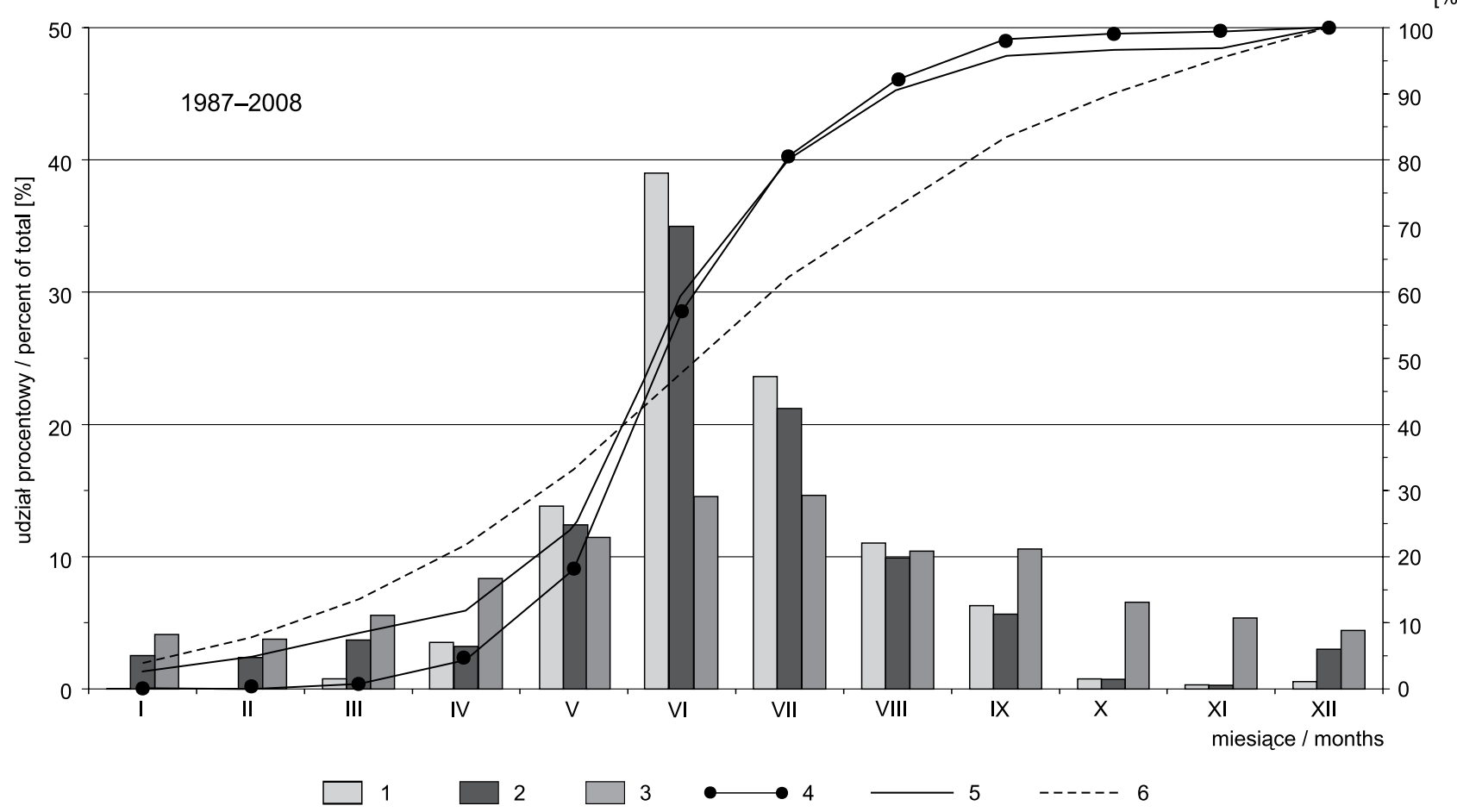

Ryc. 5. Średni miesięczny rozkład opadów (P) i wskaźników R i R (Łazy k. Bochni, 1987-2008)

1 - wskaźnik erozyjności deszczów $R_{r}, 2$ - roczny wskaźnik erozyjności $R, 3$ - miesięczna suma opadów $P, 4$ - krzywa kumulacyjna $R_{r}, 5$ - krzywa kumulacyjna R, 6 - krzywa kumulacyjna opadów P

Fig. 5. Average annual precipitation $(P)$ and $R_{r}$ and $R$ factors distribution (Lazy near Bochnia, 1987-2008)

1 - rainfall erosivity factor $R_{r}, 2$ - annual rainfall erosivity factor $R, 3$ - monthly totals of precipitation $P, 4$ - cumulative curve $R_{r}, 5$ - cumulative curve $\mathrm{R}, 6$ - cumulative curve $\mathrm{P}$ 
Tabela 3. Parametry równań regresji liniowej $(\mathrm{y}=\mathrm{a} x+\mathrm{b})$ pomiędzy miesięczną sumą opadów a miesięczną sumą wskaźnika erozyjności deszczów ( EI $_{30}$ ) (Łazy k. Bochni, 1987-2008)

Table 3. Parameters $\mathrm{a}$ and $\mathrm{b}$ of linear function $(\mathrm{y}=\mathrm{a} x+\mathrm{b})$ for the relationship between monthly totals of precipitation and monthly rainfall erosivity index $\left(\mathrm{EI}_{30}\right)$ (Lazy near Bochnia, 1987-2008)

\begin{tabular}{lcccc}
\hline \multicolumn{1}{c}{ Miesiąc } & Parametr a & Parametr b & Współczynnik determinacji $\left[\mathrm{R}^{2}\right]$ & Istotność statystyczna $[p]$ \\
\hline Kwiecień & 0,1282 & $-3,7224$ & 0,7413 & 0,000 \\
Maj & 0,6201 & $-33,747$ & 0,2371 & 0,021 \\
Czerwiec & 1,1307 & $-71,905$ & 0,5574 & 0,000 \\
Lipiec & 0,2345 & $-0,2515$ & 0,3265 & 0,006 \\
Sierpień & 0,3125 & $-11,103$ & 0,5965 & 0,000 \\
Wrzesień & $-0,1987$ & 47,266 & 0,0209 & 0,000 \\
Październik & 0,0251 & $-0,3321$ & 0,3939 & 0,002 \\
Listopad & 0,0199 & $-0,414$ & 0,1225 & 0,110 \\
\hline
\end{tabular}

$11,1 \mathrm{MJ} \mathrm{cm} \mathrm{ha} \mathrm{h}^{-1} \mathrm{~h}^{-1}$. Wartości roczne $\mathrm{R}_{\mathrm{s}}$ zmieniały się od 6,4 (1989) do 15,8 $\mathrm{MJ} \mathrm{cm} \mathrm{ha}^{-1} \mathrm{~h}^{-1}$ (2006) i były ściśle związane z miesięcznymi sumami opadów w tych latach.

\section{Zmienność wskaźnika rocznej erozyjności deszczu i spływu powierzchniowego $(R)$}

Średnia roczna z wielolecia wartość wskaźnika erozyjności deszczu i spływu (R) dla stacji meteorologicznej w Łazach wynosi 106,6 MJ cm ha ${ }^{-1} \mathrm{~h}^{-1}$. Roczne wartości wskaźnika $\mathrm{R}$ charakteryzowały się podobną zmiennością jak wskaźnika $R_{r}$, co świadczy o tym, że szacowany w sposób przybliżony wskaźnik $\mathrm{R}_{\mathrm{s}} \mathrm{W}$ niewielkim stopniu wpłynął na jego wartość (tab. 4, ryc. 6A). O wartości wskaźnika $\mathrm{R}$ decydowały deszcze o dużych natężeniach występujące głównie w maju, czerwcu, lipcu i sierpniu.
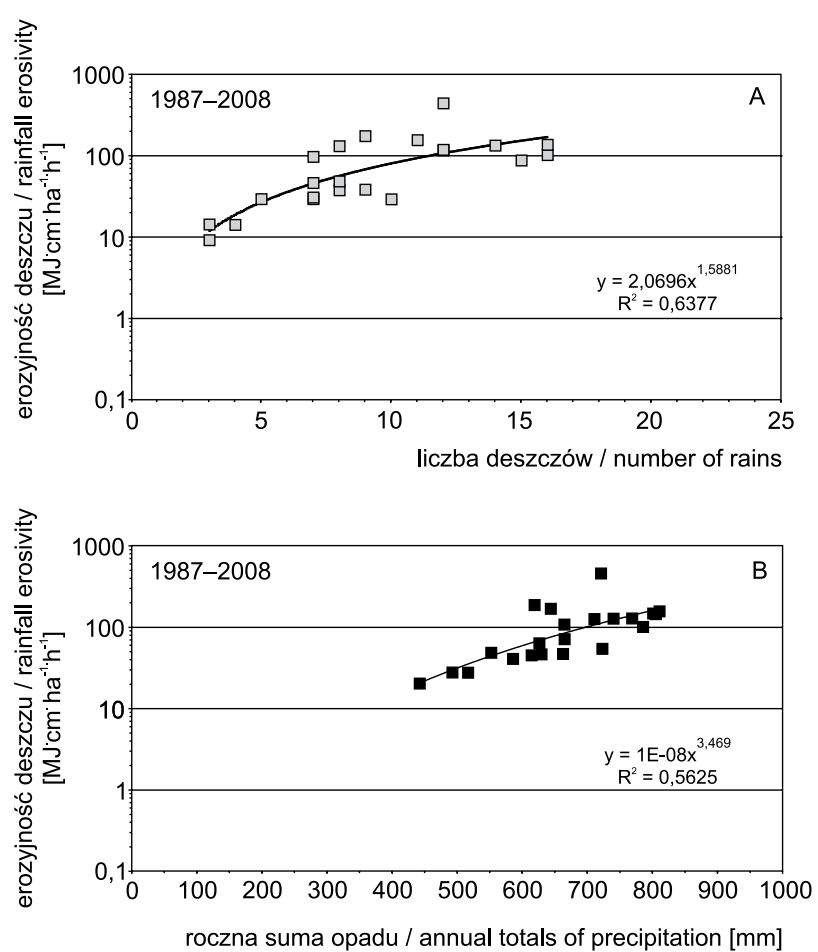

Ryc. 6. Wskaźnik $\mathrm{R}_{\mathrm{r}} \mathrm{w}$ funkcji liczby deszczów erozyjnych (A) i wskaźnik R w funkcji rocznej sumy opadów (B) (Łazy k. Bochni, 1987-2008)

Fig. 6. $\mathrm{R}_{\mathrm{r}}$ factor as a function of the number of erosive rains (A) and $\mathrm{R}$ factor as a function of annual totals of precipitation (Lazy near Bochnia, 1987-2008)
Wartość wskaźnika R wykazywała związek z rocznymi sumami opadów. Związek ten opisuje funkcja potęgowa o wysokim współczynniku korelacji $\mathrm{r}=0,75$ i poziomie istotności $\mathrm{p}=0,025$ i może być stosowany do przybliżonego szacowania wskaźnika $\mathrm{R}$ na podstawie rocznych sum opadów (ryc. 6B).

Średnie miesięczne wartości wskaźnika $\mathrm{R} z$ wielolecia były zmienne. Wysokie wartości wystąpiły w czerwcu, lipcu, maju oraz sierpniu. Najwyższą wartość odnotowano w czerwcu, w którym również wystąpiły największe dysproporcje pomiędzy średnią sumą opadów a średnią

Tabela 4. Roczna suma opadów (P) oraz roczne wartości wskaźnika erozyjności deszczów $\left(\mathrm{R}_{\mathrm{r}}\right)$, erozyjności spływów roztopowych $\left(\mathrm{R}_{\mathrm{s}}\right)$ oraz erozyjności deszczów i spływów roztopowych (R) (Lazy k. Bochni, 1987-2008)

Table 4. Annual totals of precipitations $(\mathrm{P})$ and mean annual rainfall $\left(\mathrm{R}_{\mathrm{r}}\right)$, runoff $\left(\mathrm{R}_{\mathrm{s}}\right)$ and rainfall and runoff factor $(\mathrm{R})$ (Lazy near Bochnia, 1987-2008)

\begin{tabular}{crrrr}
\hline \multirow{2}{*}{ Rok } & $\mathrm{P}$ & $\mathrm{R}_{\mathrm{r}}$ & \multicolumn{1}{c}{$\mathrm{R}_{\mathrm{s}}$} & \multicolumn{1}{c}{$\mathrm{R}$} \\
\cline { 2 - 5 }$[\mathrm{mm}]$ & \multicolumn{3}{c}{$\left[\mathrm{MJ} \cdot \mathrm{cm}^{-1} \cdot \mathrm{h}^{-1}\right]$} \\
\hline 1987 & 662,3 & 31,1 & 15,8 & 46,9 \\
1988 & 492,8 & 16,3 & 11,5 & 27,8 \\
1989 & 664,1 & 101,4 & 6,4 & 107,8 \\
1990 & 552,3 & 41,8 & 6,7 & 48,5 \\
1991 & 629,1 & 38,1 & 8,5 & 46,6 \\
1992 & 625,8 & 50,9 & 12,7 & 63,6 \\
1993 & 516,7 & 18,0 & 9,7 & 27,7 \\
1994 & 722,5 & 41,9 & 12,3 & 54,2 \\
1995 & 618,6 & 174,9 & 12,3 & 187,2 \\
1996 & 768,3 & 119,7 & 8,6 & 128,3 \\
1997 & 784,7 & 93,3 & 7,4 & 100,7 \\
1998 & 739,6 & 115,9 & 11,4 & 127,3 \\
1999 & 800,5 & 134,8 & 12,7 & 147,5 \\
2000 & 664,8 & 57,5 & 14,0 & 71,5 \\
2001 & 810,3 & 143,1 & 13,5 & 156,6 \\
2002 & 710,3 & 118,3 & 8,0 & 126,3 \\
2003 & 442,4 & 10,8 & 9,6 & 20,4 \\
2004 & 614,3 & 33,7 & 11,4 & 45,1 \\
2005 & 643,5 & 154,8 & 13,3 & 168,1 \\
2006 & 720,6 & 444,5 & 11,4 & 455,9 \\
2007 & 804,3 & 130,4 & 14,8 & 145,2 \\
2008 & 585,7 & 29,1 & 11,8 & 40,9 \\
Srednia & 662,4 & 95,5 & 11,1 & 106,6 \\
{$[\%]$} & 100,0 & 89,6 & 10,4 & 100,0 \\
\hline
\end{tabular}


Tabela 5. Wartości wskaźnika średniej rocznej erozyjności deszczów $\left(\mathrm{R}_{\mathrm{r}}\right)$, wskaźnika erozyjności spływów roztopowych ( $\left.\mathrm{R}_{\mathrm{s}}\right)$ oraz wskaźnika erozyjności deszczu i spływu powierzchniowego $(\mathrm{R})$ w różnych regionach Polski opracowane na podstawie Banasika, Górskiego (1990, 1993), Licznara, Rojka (2002), Baryły (2004) i Demczuka (2008)

Table 5. Mean annual rainfall $\left(\mathrm{R}_{\mathrm{r}}\right)$, runoff $\left(\mathrm{R}_{\mathrm{s}}\right)$ and rainfall and runoff factor $(\mathrm{R})$ in different regions of Poland elaborated on the basis Banasik, Górski (1990, 1993), Licznar, Rojek (2002), Baryła (2004), Demczuk (2008)

\begin{tabular}{|c|c|c|c|c|c|c|}
\hline \multirow[t]{2}{*}{ Region } & \multirow[t]{2}{*}{ Autor } & \multirow[t]{2}{*}{$\begin{array}{l}\text { Dhugość serii } \\
\text { pomiarowej }\end{array}$} & $\begin{array}{l}\text { Średnia } \\
\text { roczna } \\
\text { suma } \\
\text { opadów }\end{array}$ & $\begin{array}{c}\text { Wskaźnik } \\
\text { erozyjności } \\
\text { deszczu } \\
{\left[\mathrm{R}_{\mathrm{r}}\right]}\end{array}$ & $\begin{array}{c}\text { Wskaźnik ero- } \\
\text { zyjności spły- } \\
\text { wu powierzch- } \\
\text { niowego }\left[\mathrm{R}_{\mathrm{s}}\right]\end{array}$ & $\begin{array}{c}\text { Wskaźnik } \\
\text { erozyjności } \\
\text { deszczu i spły- } \\
\text { wu powierzch- } \\
\text { niowego [R] }\end{array}$ \\
\hline & & & {$[\mathrm{mm}]$} & \multicolumn{3}{|c|}{$\left[\mathrm{MJ} \cdot \mathrm{cm} \cdot \mathrm{ha}^{-1} \cdot \mathrm{h}^{-1}\right]$} \\
\hline $\begin{array}{l}\text { Suwałki } \\
\text { (Pojezierze Suwalskie) }\end{array}$ & $\begin{array}{l}\text { Banasik, Górski (1990, } \\
\text { 1992, 1993) }\end{array}$ & $1960-1988$ & 598,0 & 42,6 & 12,7 & 55,3 \\
\hline $\begin{array}{l}\text { Otwock } \\
\text { (Nizina Mazowiecka) }\end{array}$ & $\begin{array}{l}\text { Banasik, Górski (1990, } \\
\text { 1992, 1993) }\end{array}$ & $1960-1988$ & 609,0 & 57,9 & 13,6 & 71,5 \\
\hline $\begin{array}{l}\text { Puławy } \\
\text { (Wyżyna Lubelska) }\end{array}$ & $\begin{array}{l}\text { Banasik, Górski (1990, } \\
\text { 1992, 1993) }\end{array}$ & $1960-1988$ & 582,0 & 64,1 & 13,0 & 77,1 \\
\hline $\begin{array}{l}\text { Sandomierz } \\
\text { (Kotlina Sandomierska) }\end{array}$ & $\begin{array}{l}\text { Banasik, Górski (1990, } \\
\text { 1992, 1993) }\end{array}$ & $1960-1988$ & 584,0 & 66,4 & 12,1 & 78,5 \\
\hline $\begin{array}{l}\text { Limanowa } \\
\text { (Beskid Wyspowy) }\end{array}$ & $\begin{array}{l}\text { Banasik, Górski (1990, } \\
\text { 1992, 1993) }\end{array}$ & $1960-1988$ & 831,0 & 96,8 & 16,7 & 113,5 \\
\hline $\begin{array}{l}\text { Lesko } \\
\text { (Bieszczady) }\end{array}$ & $\begin{array}{l}\text { Banasik, Górski (1990, } \\
\text { 1992, 1993) }\end{array}$ & $1960-1988$ & 806,0 & 84,3 & 16,1 & 100,4 \\
\hline $\begin{array}{l}\text { Elbląg } \\
\text { (Pobrzeże Gdańskie) }\end{array}$ & $\begin{array}{l}\text { Brzozowski (1999) cyt. za } \\
\text { Baryła (2004) }\end{array}$ & $1977-1997$ & 673,5 & 59,5 & 16,3 & 75,8 \\
\hline $\begin{array}{l}\text { Wrocław-Swojec } \\
\text { (Nizina Śląska) }\end{array}$ & Licznar, Rojek (2002) & $1966-2000$ & 570,0 & 51,7 & 12,0 & 63,7 \\
\hline $\begin{array}{l}\text { Puczniew } \\
\text { (Nizina Wielkopolska) }\end{array}$ & Baryła (2004) & 1980-2002 & 545,6 & 36,7 & 11,6 & 48,3 \\
\hline $\begin{array}{l}\text { Szymbark } \\
\text { (Beskid Niski) }\end{array}$ & Demczuk (2008) & 1969-1993 & 807,0 & 93,1 & 16,1 & 109,2 \\
\hline $\begin{array}{l}\text { Łazy } \\
\text { (Pogórze Wiśnickie) }\end{array}$ & Święchowicz & $1987-2008$ & 662,4 & 95,5 & 11,1 & 106,6 \\
\hline
\end{tabular}

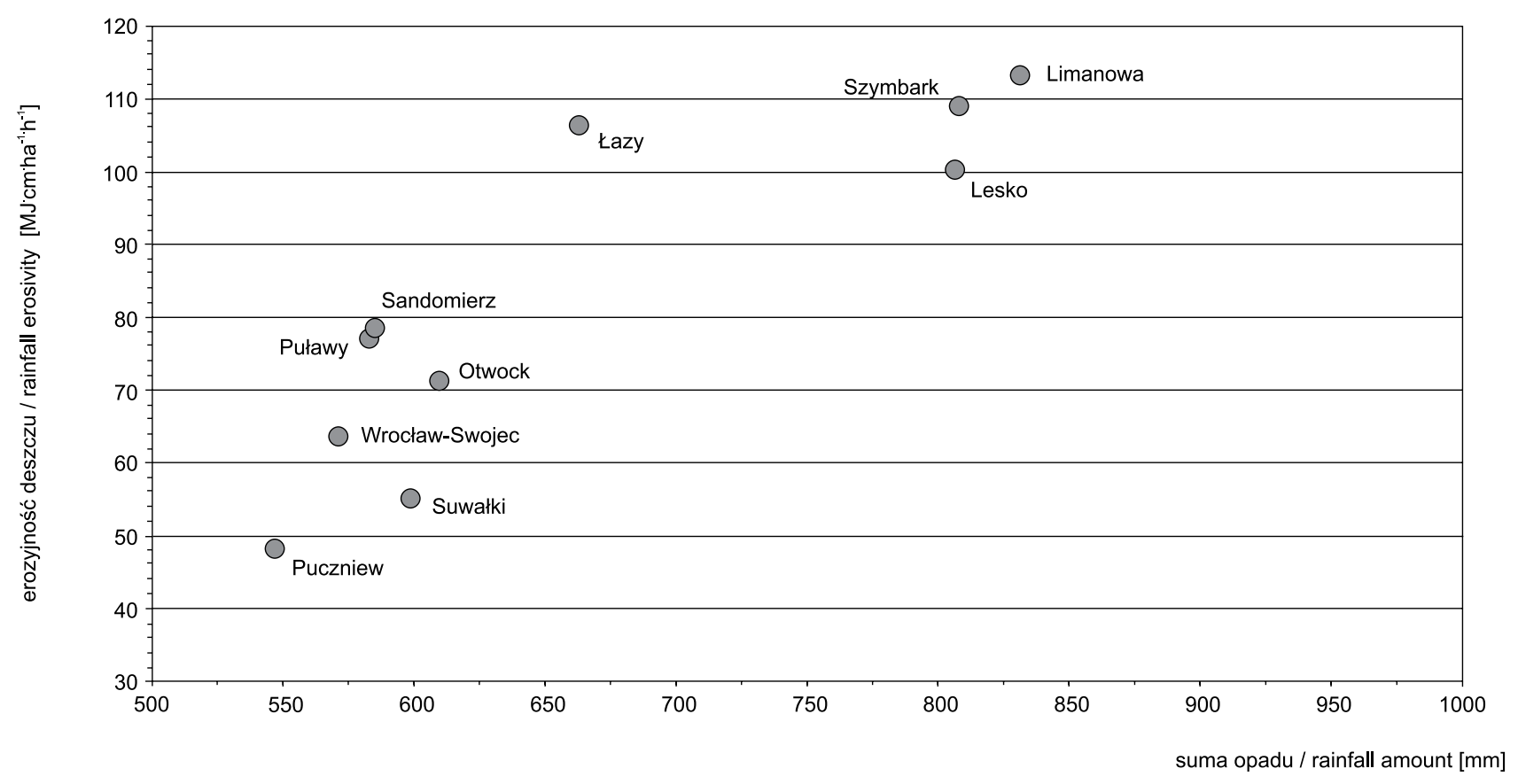

Ryc. 7. Wartości wskaźnika średniej rocznej erozyjności deszczu i spływu powierzchniowego (R) w różnych regionach Polski

Fig. 7. Mean annual rainfall and runoff factor (R) in different regions of Poland 
wartością wskaźnika R (ryc. 5). Spowodowane to było zarówno dużą częstością występowania, jak i dużym natężeniem deszczów w tym miesiącu.

Średnie wartości wskaźnika erozyjności deszczu i spływu powierzchniowego (R) dla Łazów położonych na progu Pogórza Wiśnickiego są prawie dwukrotnie wyższe od wartości obliczonych dla stacji położonych na Pojezierzu Suwalskim (Suwałki), Pobrzeżu Gdańskim (Elbląg) i Nizinie Wielkopolskiej (Puczniew), 1,3-1,5 raza wyższe od wartości obliczonych dla Kotliny Sandomierskiej (Sandomierz), Wyżyny Lubelskiej (Puławy), Niziny Mazowieckiej (Otwock) i Niziny Śląskiej (Wrocław-Swojec) (tab. 5, ryc. 7). Były również nieco wyższe, ale zbliżone do wartości uzyskanych dla Bieszczadów (Lesko), a niewiele niższe od wartości uzyskanych w Beskidzie Niskim (Szymbark) i Beskidzie Wyspowym (Limanowa) (tab. 5, ryc. 7). Jednak we wszystkich badanych regionach Karpat średnie z wielolecia sumy opadów były zdecydowanie wyższe niż w Łazach.

\section{Wnioski}

Średni roczny wskaźnik erozyjności deszczu i spływu powierzchniowego (R) z wielolecia dla stacji meteorologicznej IGiGP UJ w Łazach k. Bochni położonej na niższym stopniu progu Pogórza Wiśnickiego (Przedgórze Brzeskie) wynosi $106,6 \mathrm{MJ} \mathrm{cm} \mathrm{ha}^{-1} \mathrm{~h}^{-1}$. Jest to wartość zdecydowanie wyższa od wartości podawanych dla Polski północno-wschodniej (Suwałki), północnej (Elbląg), zachodniej (Wrocław-Swojec) i środkowej (Puczniew, Otwock, Puławy, Sandomierz). Natomiast wartość wskaźnika $\mathrm{R}$ jest nieco wyższa od wartości podawanych dla Bieszczadów, trochę tylko niższa od wartości podawanych dla brzeżnej części Beskidu Niskiego (Szymbark) i niższa od wartości podawanych dla Beskidu Wyspowego (Limanowa). Jednak we wszystkich badanych regionach Karpat średnie z wielolecia sumy opadów były zdecydowanie wyższe niż w Łazach.

Roczne wartości wskaźnika R dla Łazów w wieloleciu zmieniały się w szerokim zakresie od 20,4 (2003) do 455,9 $\mathrm{MJ} \mathrm{cm} \mathrm{ha}^{-1} \mathrm{~h}^{-1}$ (2006). Zmiany te w większym stopniu związane były $\mathrm{z}$ występowaniem deszczów o dużej erozyjności niż $z$ rocznymi sumami opadów w danym roku.

Najwięcej deszczów o dużym wskaźniku erozyjności występowało zazwyczaj w czerwcu i lipcu. Zdarzały się również w sierpniu i w maju. Siła związku pomiędzy miesięcznymi wartościami wskaźnika $\mathrm{R}_{\mathrm{r}}$ i miesięcznymi sumami opadów w kwietniu oraz w sierpniu i czerwcu jest duża, natomiast we wrześniu, październiku i listopadzie jest mała.

Średnia roczna wartość wskaźnika spływów roztopowych $\mathrm{R}_{\mathrm{s}}$ dla Łazów wynosi $11,1 \mathrm{MJ} \mathrm{cm} \mathrm{ha}^{-1} \mathrm{~h}^{-1}$ i stanowi zaledwie 10,4\% średniej rocznej $\mathrm{z}$ wielolecia wartości wskaźnika R.

\section{Podziękowania}

Dziękuję anonimowemu recenzentowi za wartościowe uwagi, które wzbogaciły pracę i nadały jej ostateczny kształt. Jestem wdzięczna Alicji Waligórze-Zblewskiej za tłumaczenie na język angielski. Praca naukowa finansowana przez Ministerstwo Nauki i Szkolnictwa Wyższego ze środków na naukę w latach 2008-2010 jako projekt badawczy nr NN 306048334.

\section{Literatura}

Arnoldus HM., 1978. An approximation of the rainfall factor in the Universal Soil Loss Equation.W: M. De Boodst, D. Gabriels (red.), Assessments of Erosion. John Wiley \& Sons, Inc., New Cork: 127-132.

Banasik K., Górski D., 1990. Wyznaczanie erozyjności deszczy do uniwersalnego równania strat glebowych. Zeszyty Naukowe AR Wrocław, Melioracja 34: 103-109.

Banasik K., Górski D., 1993. Evaluation of rainfall erosivity for east Poland. W: K. Banasik, A. Żbikowski (red.), Runoff and sediment yield modelling. Agricultural University Press, Warszawa: 129-134.

Banasik K., Skibiński J., Górski D., 1995. Metody oceny powierzchniowej i akumulacji rumowiska w zbiornikach. W: K. Banasik (red.), Metodyka zagospodarowania zasobów wodnych w małych zlewniach rzecznych. Wydawnictwa SGGW, Warszawa: 63-76.

Baryła A., 2004. Erozyjność deszczy w rejonie Puczniewa. Przegląd Naukowy Inżynierii i Kształtowania Środowiska 13 2(29): 48-54.

Brown L.C., Foster G.R., 1987. Storm erosivity using idealized intensity distributions. Transactions of the American Society of Agricultural Engineers 30: 379-386.

Capolongo D., Diodato N., Manaerts C.N., Piccarreta M., Strobl R.O., 2008. Analyzing temporal changes in climate erosivity using a simplified rainfall erosivity model in Basilicata (southern Italy). Journal of Hydrology 356: 119-130.

Cebulska M., Szczepanek R., Twardosz R., 2013. Rozkład przestrzenny opadów atmosferycznych w dorzeczu górnej Wisły. Opady średnie roczne (1952-1981). IGiGP UJ, Kraków: 1-84.

Coutinho M.A., Tomas P.P., 1994. Comparison of Fournier with Wischmeier rainfall erosivity indices. W: R.J. Rickson (red.), Conservation Soil Resources, European Perspectives. CAB International, Wallingford: $192-200$.

Demczuk P., 2008. Wpływ współczynnika erozyjności deszczu na wielkość erozji gleb w zlewni Bystrzanki w latach 1969-1993. W: A. Kostrzewski, W. Bochenek (red.), Konferencja Jubileuszowa z okazji 40-lecia działalności Stacji Naukowo-Badawczej IGiPZ PAN w Szymbarku. XVIII Ogólnopolskie Sympozjum Zintegrowanego Monitoringu Środowiska Przyrodniczego. Streszczenia referatów i posterów: 15 .

Demczuk P., 2009. Wpływ erozyjności deszczu na wielkość erozji gleb w zlewni Bystrzanki w latach 1969-1993. W: W. Bochenek, M. Kijowska (red.), Funkcjonowanie środowiska przyrodniczego w okresie przemian gospodarczych w Polsce. Biblioteka Monitoringu Środowiska, Szymbark: 231-238.

Dijk van A.I.J.M., Bruijnzeel L.A., Rosewell C.J., 2002. Rainfall intensity - kinetic energy relationships: a critical literature appraisal. Journal of Hydrology 261: 1-23.

Diodato N., 2004. Estaimating RUSLE's rainfall factor in the part of Italy with a Mediterranean rainfall regime. Hydrology and Earth System Sciences 8(1): 103-107.

Dreger J. (red.), 1981. Przewodnik do ćwiczeń z meteorologii i klimatologii dla studentów geografii. Wydawnictwa Uniwersytetu Warszawskiego, Warszawa: 1-213.

Fornis R.L., Vermeulen H.R., Nieuwenhuis J.D., 2005. Kinetic energy rainfall relationship for Central Cebu. Philippines for soil erosion. Journal of Hydrology 300: 20-32.

Fournier F., 1960. Climat et Erosion; la relation entre l'érosion du sol par l'eau et les précipitations atmosphériques. Paris Presses Univ. de France, Paris: 1-201. 
Gilewska S., Starkel L., 1979. Geomorfologia. W: Atlas województwa krakowskiego. Polska Akademia Nauk, Kraków: 10.

Gilewska S., Starkel L., 1988. Geomorfologia. W: Atlas województwa tarnowskiego. Polska Akademia Nauk, Kraków: 9.

Janeček M., Kubátová E., Tippl M., 2006. Revised Determination of the Rainfall-runoff Erosivity Factor R for Application of USLE in the Czech Republic. Soil \& Water Resourses 1(6): 65-71.

Janeček M., Kvetoň V., Kubátová E., Kobzová D., 2012. Differentiation and Regionalization of Rainfall Erosivity Factor Values in the Czech Republic. Soil \& Water Resourses 1(7): 1-9.

Janeček M., Květoň V., Kubátová E., Kobzová D., Vošmerová M., Chlupsová J., 2013. Values of rainfall erosivity factor for the Czech Republic. Journal of Hydrology and Hydromechanics 61(2): 97-102.

Józefaciuk A., Józefaciuk C., 1995. Erozja agroekosystemów. Biblioteka Monitoringu Środowiska, Warszawa: 1-168.

Kaczorowska Z., 1962. Opady w Polsce w przekroju wieloletnim. Prace Geograficzne IGPAN 33: 1-112.

Licznar P., 2005. Ocena możliwości stosowania sztucznych sieci neuronowych dla określania średniej rocznej wartości wskaźnika erozyjności deszczy. Acta Agrophysica 5(1): 65-74.

Licznar P., Łomotowski J., 2005. Analiza chwilowych natężeń deszczów miarodajnych we Wrocławiu. Ochrona Środowiska 27(2): 25-28.

Licznar P., Łomotowski J., Rojek M., 2005. Zintegrowany system pomiarów opadów atmosferycznych dla potrzeb badań nad erozją wodną. Acta Agrophysica 5(2): 335-344.

Licznar P., Rojek, M., 2002. Erozyjność deszczy Polski południowo-zachodniej na przykładzie stacji Wrocław-Swojec. Przegląd Naukowy SGGW, Inżynieria i Kształtowanie Środowiska 11(2): 5-14.

Loureiro N.S., Coutinho M.A., 2001. A new procedure to estimate the RUSLE $\mathrm{EI}_{30}$ index, based on monthly rainfall data and applied to the Algarve region, Portugal. Journal of Hydrology 250: 12-18.

Malíšek A., 1990. Assessment of the factor of rainstorm erosivity (in Slovak). Geografický časopis 42: 410-422.

Meusburger K., Steel A., Panagos P., Montanarella L., Alewell C., 2012. Spatial and temporal variability of rainfall erosivity factor for Switzerland. Hydrology and Earth System Sciences 16: 167-177.

Niedźwiedź T., Obrębska-Starklowa B., 1991. Klimat. W: I. Dynowska, M. Maciejewski (red.), Dorzecze górnej Wisły. Część I. PWN, Warszawa-Kraków: 68-84.

Nyssen J., Vandenreyken H., Poesen J., Moeyersons J., Deckers J., Mitiku Haile, Salles C., Govers G., 2005. Rainfall erosivity and varaibility in the Northern Ethiopian Highlands. Journal of Hydrology 311: $172-187$.

Obi M.E., Salako F.K., 1995. Rainfall parameters influencing erosivity in southeastern Nigeria. Catena 24(4): 275-287.

Oduro-Afriyie K., 1996. Rainfall erosivity map for Ghana. Geoderma 74: 161-166.

Qi H., Gantzer C.J., Jung P.K., Lee B.L., 2000. Rainfall erosivity in the Republic of Korea. Journal of Soil Water Conservation 55: 115-120.

Pauwelyn P.L.L., Lenvain J.S., Sakala W.K., 1988. Iso-erodent map of Zambia. Pt I. Calculation of erosivity indices from a rainfall databank. Soil Technology 1(3): 235-251.

Pruchnicki J., 1987. Metody opracowań klimatologicznych. PWN, Warszawa: 1-203.

Rejman J., 2006. Wpływ erozji wodnej i uprawowej na przekształcenie gleb i stoków lessowych. Acta Agrophysica 136(3): 1-90.

Renard K.G., Foster G.R., Weesies G.A., McCool D.K., Yoder D.C., 1997. Predicting Soil Erosion by Water: A Guide to Conservation
Planning With the Revised Universal Soil Loss Equation (RUSLE). U.S. Department of Agriculture, Agriculture Handbook 703.

Salako F., 2008. Rainfall variability and kinetic energy in Southern Nigeria. Climate Change 86: 151-164.

Salles C., Poesen J., Sempere-Torres D., 2002. Kinetic energy of rain and its functional relationship with intensity. Journal of Hydrology 257: $256-270$.

Silva da A.M., 2004. Rainfall erosivity map of Brazil. Catena 57: 251259.

Smolska E., 2010. Spływ wody i erozja gleby na piaszczystym stoku w obszarze młodo glacjalnym - pomiary poletkowe (Pojezierze Suwalskie, Polska NE). W: E. Smolska, J. Rodzik (red.), Procesy erozyjne na stokach użytkowanych rolniczo (metody badań, dynamika i skutki). Prace i Studia Geograficzne WGiSR UW 45: 197-214.

Starkel L., 1988. Rzeźba. W: J. Warszyńska (red.), Województwo tarnowskie - monografia. PAN, Kraków: 19-28.

Stępniewski K., Demczuk P., Rodzik J., Siwek K., 2010. Związki między opadem deszczu a spływem powierzchniowym i spłukiwaniem gleby na poletkach doświadczalnych o różnym użytkowaniu (Guciów - Roztocze Środkowe). W: E. Smolska, J. Rodzik (red.), Procesy erozyjne na stokach użytkowanych rolniczo (metody badań, dynamika i skutki). Prace i Studia Geograficzne WGiSR UW 45: 229-241.

Szewrański S., 2009. Rozbryzg jako forma erozji wodnej gleb lessowych. Wydawnictwo Uniwersytetu Przyrodniczego, Wrocław: 1-138.

Š́ri M., Cebecauer T., Hofierka J., Fulajtár E., 2002. Soil Erosion Assessment of Slovakia at a Regional Scale Using GIS. Ecology (Bratislava) 21(4): 404-422.

Święchowicz J., 2002. Współdziałanie procesów stokowych i fluwialnych w odprowadzaniu materiału rozpuszczonego i zawiesiny ze zlewni pogórskiej. Instytut Geografii UJ, Kraków: 1-150.

Święchowicz J., 2010. Spłukiwanie gleby na użytkowanych rolniczo stokach pogórskich w latach hydrologicznych 2007-2008. W: E. Smolska, J. Rodzik (red.), Procesy erozyjne na stokach użytkowanych rolniczo (metody badań, dynamika i skutki). Prace i Studia Geograficzne WGiSR UW 45: 243-263.

Święchowicz J., 2012a. Wartości progowe parametrów opadów deszczu inicjujących procesy erozyjne w zlewniach użytkowanych rolniczo. Instytutu Geografii i Gospodarki Przestrzennej UJ, Kraków: 1-282.

Święchowicz J., 2012b. Water erosion on agricultural foothill slopes (Carpathian Foothills, Poland). Zeitschrift für Geomorphologie 56 (3): $21-35$.

Wischmeier W.H., Smith D.D., 1958. Rainfall energy and its relationship to soil loss. Transactions of the American Geophysist Union 39: 285-291.

Wischmeier W.H., Smith D.D., 1959. A rainfall erosion index for a universal soil loss equation. Soil Science Society of America Proceedings 23: 246-249.

Wischmeier W.H., Smith D.D., 1965. Predicting rainfall-erosion losses from cropland east of the Rocky Mountains - Guide for selection of practices for soil and water conservation. U.S. Department of Agriculture, Washington D.C. Agricultural Handbook 282.

Wischmeier W.H., Smith D.D., 1978. Predicting rainfall erosion losses - a guide to conservation planning. Department of Agriculture, Washington D.C, Agricultural Handbook 537.

Zanchi C., Torri D., 1980. Evaluation of rainfall energy in central Italy. W: M. De Boodt, D. Gabriels (red.) Assessment of Erosion. John Wiley, Toronto: 133-142. 